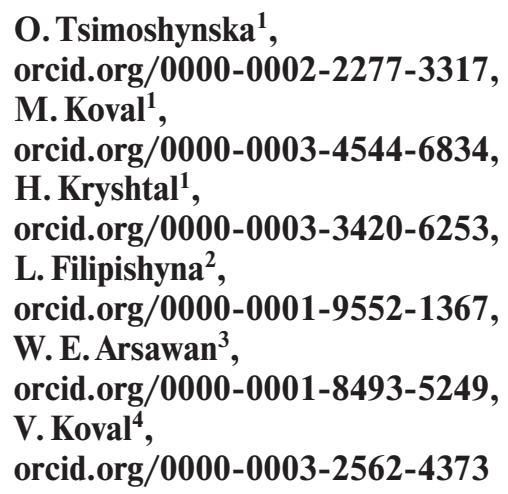

1 - Interregional Academy of Personnel Management, Kyiv, Ukraine, e-mail: ovmichailenko@ukr.net

2 - National university of life and environmental sciences of Ukraine, Kyiv, Ukraine

3 - Politeknik Negeri Bali, Bali, Indonesia

4 - Odesa Institute of Trade and Economics of Kyiv National

University of Trade and Economics, Odesa, Ukraine

\title{
INVESTING IN ROAD CONSTRUCTION INFRASTRUCTURE PROJECTS UNDER PUBLIC-PRIVATE PARTNERSHIP IN THE FORM OF CONCESSION
}

Purpose. To substantiate an approach to road development investment management in Ukraine in compliance with the principle of syncretism and the use of Quality Function Deployment methodology, to improve the methodological approach to calculating the concession fee for brown-field and green-field road concession projects.

Methodology. The study used a set of general and special methods of cognition: the Quality Function Deployment (QFD) method, the environmental approach, multimodal analysis, Decoupling Index, Decoupling Factor, logical generalization, quantitative and qualitative comparison, scientific abstraction and systematization.

Findings. According to the results of research on interrelation of cost of an investment project and volumes of works by their types, an economic-mathematical model of estimation of need for investments in projects for construction, reconstruction, repair and maintenance of public motor roads is offered. The proposed model, unlike the existing ones, is based on lateral understanding of the clarity of delineation of capital needs by type of road construction, which will provide taking management decisions on investment projects with model and information tools that will help obtain the most realistic assessment of need for capital needed to improve the transport operation condition of motor roads in Ukraine.

Originality. The organizational-economic mechanism of management of investment activity of road economy and the estimation of efficiency of co-financing investment projects under programs on construction, reconstruction, repair and maintenance of motor roads is advanced. The diagnostics of efficiency of investment of construction of public motor roads under public-private partnership in the form of concession is improved.

Practical value. The results of the study can be used in the activities of road industry of Ukraine for the development and implementation of investment projects under motor road development programs.

Keywords: motor roads, investments, investment activity management, infrastructure projects, public-private partnership

Introduction. Sustainable and efficient functioning of transport infrastructure is a necessary condition for stabilization, recovery and restructuring of the economy, for ensuring the integrity, security and defence capabilities of the state, for improving the living standard and conditions of its citizens.

The development of transport infrastructure ensures an increase in the competitiveness of economy, as the intensification of investment activities in the road sector, in particular under public-private partnership in the form of concession using a system of tax incentives for concessionaires, is the basis for improving and developing motor roads.

Transport generates intersectoral services and creates the appropriate infrastructure of a country, as the demand for transport services largely depends on the demand for the results of activities of other sectors of the economy. A key factor in the functioning and development of transport infrastructure is the state of the country's transport routes [1], according to which Ukraine, unfortunately, ranks $134^{\text {th }}$ out of 138 countries that participated in the Global Competitiveness Report 2018.

Highly developed European countries, world leaders in economic development, which include Japan, are constantly increasing their infrastructural potential, as evidenced by the data given in Table 1 [2].

As we can see, the development of road network in any country of the world, on the one hand, is a consequence of the development of its economy, and on the other hand, one of the key factors contributing to this development [2].

(C) Tsimoshynska O., Koval M., Kryshtal H., Filipishyna L., Arsawan W. E., Koval V., 2021
Literature review. Studies on management of road sector investment activities are conducted in a work by Hughes J. F. and Healy K. (2014), who examined the critical infrastructure and natural, technological, social and political hazards of the functioning of transport system as well as the technical and organizational level of its sustainability.

In research $[3,4]$ the content of investment activity management is studied interpreting investment activity broader as an organized activity carried out in the actual, existing in the country's business conditions through practical actions of investment entities, whose functions consist in the purposeful process of finding the required number of investment resources, selecting appropriate objects or tools for investment, developing and implementing a phased investment program or strategy and ensuring its effective implementation in order to make a profit and/or cause some other positive effect. Undoubtedly, this definition is correct, but we are convinced that the concept of "investment activity" should be considered in the context of expectations of stakeholders as for its success [4].

While ensuring the success of investment activities is possible under condition of effective management, which, in a broad sense, should be considered as the application of special knowledge and methods to meet the expectations of investment process participants, and in a narrower sense, one should separately focus on each of specific scientific approaches.

Since management of investment activities is the coordination of certain actions, it is carried out due to the influence of a set of management tools, which activates a certain management mechanism. 
Comparative analysis of the length and density of roads in Ukraine, some EU countries and Japan (2018)

\begin{tabular}{|l|c|c|c|}
\hline \multicolumn{1}{|c|}{ Country } & $\begin{array}{c}\text { Country area, } \\
\text { thousand } \mathrm{km}^{2}\end{array}$ & $\begin{array}{c}\text { Motor roads } \\
\text { length, } \\
\text { thousand } \mathrm{km}\end{array}$ & $\begin{array}{c}\text { Motor roads } \\
\text { density, km. per } \\
1000 \mathrm{~km}^{2} \text { of the } \\
\text { territory }\end{array}$ \\
\hline Ukraine & 603.7 & 169.5 & 274.7 \\
\hline Japan & 377.8 & 1219.0 & 3231.3 \\
\hline Great Britain & 244.1 & 418.0 & 1713.2 \\
\hline Poland & 312.6 & 424.0 & 1355.9 \\
\hline France & 551.6 & 1050.6 & 1749.1 \\
\hline Germany & 357.0 & 644.5 & 1805.3 \\
\hline Spain & 307.6 & 683.2 & 1349.5 \\
\hline Italy & 301.2 & 669.0 & 1618.7 \\
\hline
\end{tabular}

In particular, the works $[5,6]$ insist on the need to consider the concept of "investment management" according to an integrated approach, as a systemically integrated process of managing a set of investment projects which are subject to a single strategic goal focused on successful implementation of its investment program.

The purpose of the article is to substantiate an approach to road development investment management in Ukraine in compliance with the principle of syncretism and the use of Quality Function Deployment methodology, to improve the methodological approach to calculating the concession fee for brown-field and green-field road concession projects.

Methods. Management of investment activity is the guarantee of its success, and the quality of management of investment activity is the ability to meet the expectations of stakeholders as for successful implementation of investment programs and projects. Therefore, management of investment activities should be considered on the basis formed by the methods of Quality Function Deployment (QFD) - methods for making management decisions that are based on the structuring (deployment) of the quality function of a particular product. The QFD methodology has gained worldwide recognition and is one of the mandatory requirements of QS-9000 and ISO 9000:2015 Standard "Quality Management Systems - Fundamentals and Vocabulary" (ISO (2018). 9000:2015, Quality

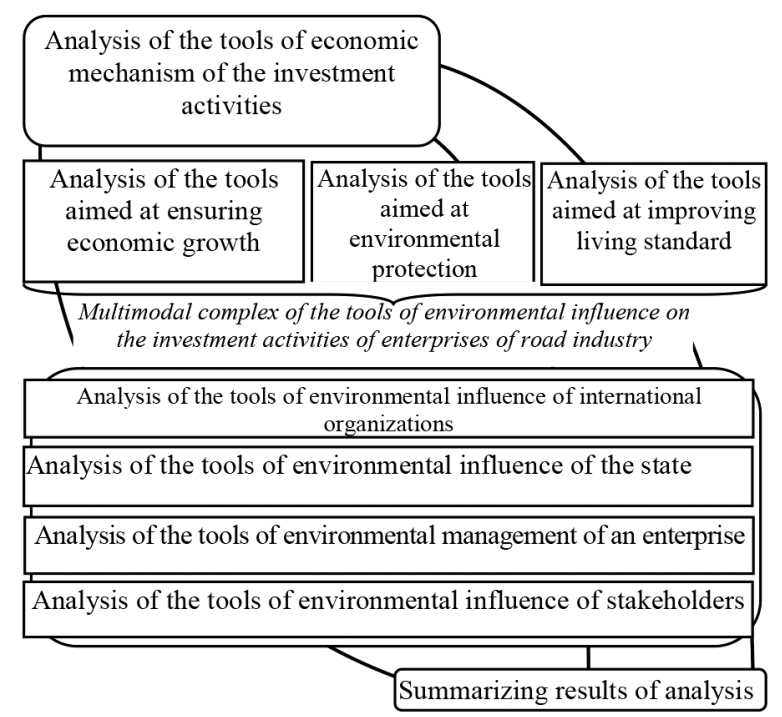

Fig. 1. Scheme of the application of environmental approach to management of the investment activities of road industry in Ukraine management systems. Fundamentals and vocabulary, European Committee for Standardization, Brussels.). According to the QFD methods, the requirements of stakeholders for the formation of a mechanism of investment activity management should be specified in stages, starting with determining the need for tool and ending with the evaluation of its effectiveness (Fig. 1).

The study also uses an environmental approach to managing the investment activities of road sector, which consists in combining economic growth with environmental protection and improving the quality of life, which is complemented by multimodal analysis of the process and result of interaction of its tools (Fig. 1), which will contribute to the systematization and consistency of transformations at all levels of the hierarchy of management of investment activities of the country's road industry.

The environmental approach to management of the investment activities of road sector aimed at preserving the environment is characterized by the phenomenon of decoupling. Decoupling (or decoupling effect) is characterized by indicators of Decoupling Index and Decoupling Factor, which are determined according to the formulas

$$
\text { Decoupling Index }=\frac{\left(\frac{E P}{D F}\right)_{\text {endinq }}}{\left(\frac{E P}{D F}\right)_{\text {beqinin }}} ;
$$$$
\text { Decoupling Factor = } 1 \text { - Decoupling Index, }
$$

where EP (environmental pressure) is the anthropogenic pressure on the environment; $D F$ (driving force) represents indicators of economic growth in the ending and beginning periods of the study.

Results. The development of national economy under the conditions of environmentalization requires revision of the methodological basis of doing business, clarification of its objects, the technology of data collection and processing in order to create an effective organizational and economic mechanism of managing, primarily, the investment activities of transport infrastructure $[8,9]$.

Sustainable and efficient functioning of the transport infrastructure is a necessary condition for stabilization, recovery and restructuring of the economy, for ensuring the integrity, security and defense capabilities of the state, for improving the living standard and conditions of its citizens.

Ukraine's signing of the Association Agreement with the EU was a clear manifestation of the country's desire to be part of the European community through political association and economic integration based on common values, which are the rule of law and respect for human rights and freedoms. Ukraine's commitments under the Association Agreement are a roadmap for reforming the country. Currently, the EU provides support to Ukraine through various programs and using various mechanisms, which include, in particular, the financing of infrastructure projects - projects for the development of roads and transport infrastructure (Cabinet of Ministers of Ukraine (2015). Some issues of reforming the system of public administration of public roads.). Ukraine has new opportunities to develop trade relations, expand industrial ties and intensify scientific and technical cooperation with European countries. Under these conditions, the question of ability of Ukraine's national transport system to integrate into the European transport system, become part of it and thus meet both Ukraine's national transport needs and the needs of the EU as its strategic partner is burning. But the land transport arteries of Ukraine - its roads built in Soviet times - have exhausted their resources and need $100 \%$ restoration of the road surface in accordance with modern loads and traffic intensity, namely the road network is waiting for further development.

Every year, the load on highways, especially transit routes, increases significantly [3]. Given the deep-rootedness of problem of investing in the development of motor roads and trans- 
port infrastructure of country, it becomes clear that its solution requires significant funds over a significant period of time.

In order to improve the organizational support of investment activities of road industry and the adaptation of Ukrainian legislation to the legislation of the European Union, a draft Law of Ukraine "On Amendments to Certain Legislative Acts of Ukraine on Regulation of the Road Transport Market in Ukraine to Bring It in Alignment with the European Union Act" (Verkhovna Rada of Ukraine. 2017) has been developed; it proposes the introduction into the domestic practice of EU Directives (of the European Parliament and Council), which will contribute to: development of motor roads and the transport infrastructure in accordance with the requirements of European standards; introduction of effective control over the functioning of road transport market; improvement of the quality of transport services and the level of safety in motor transport.

It is known that the most pressing issue in the process of construction of motor roads and transport infrastructure is to ensure their proper financing, using various possible sources, including the private sector.

In our opinion, only the introduction of public-private partnership will ensure guaranteed investment, equal and transparent conditions for participation in tenders, differentiation of types of work in road maintenance distinguishing between permanent and periodic ones can significantly intensify the market of construction, repair and maintenance of roads in Ukraine. The experience of European countries proves this.

In the most general form, the effectiveness of organizational and economic mechanism for managing the investment activities of road sector should be understood as the effect obtained as a result of the functioning of tools aimed at achieving the main objectives of investing in road construction and improving road condition. And since the tools for managing the investment activities of road sector are generally divided into tools for administrative-legal and economic impact, then, when conducting a multimodal analysis of the interaction of plurality of its tools, one should focus on the analysis of both legal and economic regulation of investment activities [10]. In this case, the evaluation criteria and indicators should meet the main objectives of state regulation of the process of investing in the development of roads and transport infrastructure.

Unfortunately, the current regulations on management of investment activities in the road sector do not contain clear and measurable indicators and do not provide for mechanisms for monitoring the effectiveness of tools as for the attainability of objectives of investing in construction, reconstruction and repair of motor roads (including statistical data collection relevant just for this purpose), which significantly complicates carrying out a multimodal analysis of the interaction of plurality of tools of organizational and economic mechanism for managing the investment activities of road sector.

No less important in the study on investment management of the road sector is the evaluation of effectiveness of tools of economic impact, the methodology of implementation of which is determined primarily by the mechanism of financing road works carried out by:

- budget funds;

- funds of International Financial Organizations (EBRD, IBRD, EIB);

- funds of private investors.

Thus, for example, the EBRD and the EIB agreed upon the fact that the share of each bank in financing the project "Motor Road and Traffic Safety Improvement Project in Ukraine" in 2018 amounted to 474 million US dollars (Table 2) [11].

According to Table 2, during the period we studied, the sample of IBRD loans amounted to 320.9 million US dollars, which was only $71 \%$ of the total amount of loan provided for by the Loan Agreement. Thus, the outstanding loan, as of the

Table 2

Characteristics of partial indicators of the research component index of information economy development

\begin{tabular}{|c|c|c|c|c|}
\hline Sources of financing & $\begin{array}{l}\text { During the year } \\
\text { that ended } \\
\text { December } 31\end{array}$ & $\begin{array}{l}\text { During the whole } \\
\text { period of implementing } \\
\text { the Project }\end{array}$ & $\begin{array}{l}\text { Budget } \\
\text { of financing }\end{array}$ & $\begin{array}{l}\text { Outstanding } \\
\text { loan }\end{array}$ \\
\hline \multicolumn{5}{|c|}{2014} \\
\hline funds of IBRD & 66.349 & 167.350 & 450.000 & 282.650 \\
\hline funds of the State Road Agency of Ukraine & 6.640 & 19.156 & 19.156 & - \\
\hline Total & 72.989 & 186.506 & 469.156 & 282.650 \\
\hline \multicolumn{5}{|c|}{2015} \\
\hline funds of IBRD & 44.614 & 211.964 & 450.000 & 238.036 \\
\hline funds of the State Road Agency of Ukraine & 5.247 & 24.403 & 24.403 & - \\
\hline Total & 49.861 & 236.367 & 474.403 & 238.036 \\
\hline \multicolumn{5}{|c|}{2016} \\
\hline funds of IBRD & 20.308 & 232.272 & 450.000 & 217.728 \\
\hline funds of the State Road Agency of Ukraine & - & 24.403 & 24.403 & - \\
\hline Total & 20.308 & 256.675 & 474.403 & 217.728 \\
\hline \multicolumn{5}{|c|}{2017} \\
\hline funds of IBRD & 24.225 & 256.497 & 450.000 & 193.503 \\
\hline funds of the State Road Agency of Ukraine & - & 24.403 & 24.402 & - \\
\hline Total & 24.225 & 280.900 & 474.402 & 193.503 \\
\hline \multicolumn{5}{|c|}{2018} \\
\hline funds of IBRD & 64.416 & 320.913 & 450.000 & 129.087 \\
\hline funds of the State Road Agency of Ukraine & - & 24.403 & 24.403 & - \\
\hline Total & 64.416 & 345.316 & 474.403 & 129.087 \\
\hline
\end{tabular}


end of 2018, amounted to more than 129 million US dollars. The reasons for this were the delay and long duration of approval of lists of sites and implementation of procedures related to the opening of funding, which led to a delay in the development of project documentation and, accordingly, a delay in conducting procurement procedures. Therefore, the effectiveness of mechanism of co-financing road development projects using MFI funds, unfortunately, was reduced to zero.

The actions and interaction of the components of the existing mechanism for co-financing investment projects for the construction, reconstruction, repair and maintenance of highways at the expense of IFI funds may be ineffective for the following reasons:

- the first is the long-term imbalance of public finance system, which is one of the preconditions for the devaluation of hryvnia and the deepening of economic crisis;

- the second consists in the imperfections of current national legislation on the competitive selection of contractors. In foreign practice, for example, the registration of unscrupulous contractors has been introduced. Under the European law, unscrupulous contractors are subject to restrictive measures concerning their participation in tenders for the next five years from the date of entry in the Register of Unscrupulous Contractors as well as full liability for late performance of contracts and undue termination of contracts;

- the third is represented by the imperfections of management system of the State Road Agency. Today, the State Agency is a vertically integrated holding company that, for itself, orders works, performs them and controls them. Thus, the Agency created Ukrainian Road Investments State Company, which belongs to its sphere of management, and annually procured from it services for the implementation of investment projects under the procedure of procurement from one participant. Therefore, there are many opportunities for abuse in such a scheme of activity, and the advantages of healthy competition a priori do not exist, because the latter is not created at all.

Given the above, we conclude that the existing mechanism for co-financing road development projects needs to be significantly modified. The following vectors should be recognized the main vectors of strengthening its effectiveness:

- introduction of "dosed" moderate tolerant selection of investment projects from many possible options under conditions of active manipulation of destabilizing factors, introduction of systems of instability control and limited chaotization of financing investment activities of the road sector, which will ensure efficient capital investment and reduce credit load on regional motor road services;

- increasing the level of competition in the market and creating comfortable working conditions for foreign contractors;

- introduction of long-term road cost planning practice.

The world practice of road construction testifies to the success and efficiency of using concessions as a tool to attract private sector investments in the road sector. In Ukraine, the relations of private sector with the state concerning investment in the construction and operation of motor roads are also, in a certain manner, regulated by law, but so far, none of the concession projects has been implemented in the industry [12]. The reasons for this are as follows:

- unfavorable investment climate in the country, a high level of dependence of the concessionaire on unstable and changing business conditions;

- the concession legislation lacking the necessary regulation of state guarantees, insurance and tax incentives for capital investments of the concessionaire and partnership risk sharing;

- low intensity of traffic flow;

- lack of price plans for the cost of travel per kilometer;

- low level of solvency of the population and its objective disinterest in toll motor roads;

- difficulties in creating an effective financial model of concession relations, and others.

Therefore, there is every reason to believe that the distinguishing feature of the Ukrainian concession is its perception by government agencies as a last resort in the issue of finding sources of capital investment - and this approach destroys the very essence of concession relations, which should be built on partnership principles.

Under the scheme of Ukrainian concession (Fig. 3), property created to fulfill the terms of concession agreement or received under the concession is the object of state ownership right, which is transferred to the concessionaire in possession and use for the term of agreement. The concessor (State Road Agency of Ukraine), upon completion of the construction and commissioning of the facility is obliged to pay the concessionaire a fee for the operational readiness of road. In turn, the concessionaire is obliged (regardless of the results of economic activity) to pay the concession fees from the moment of receiving the income from the operation of motor road. In case of low

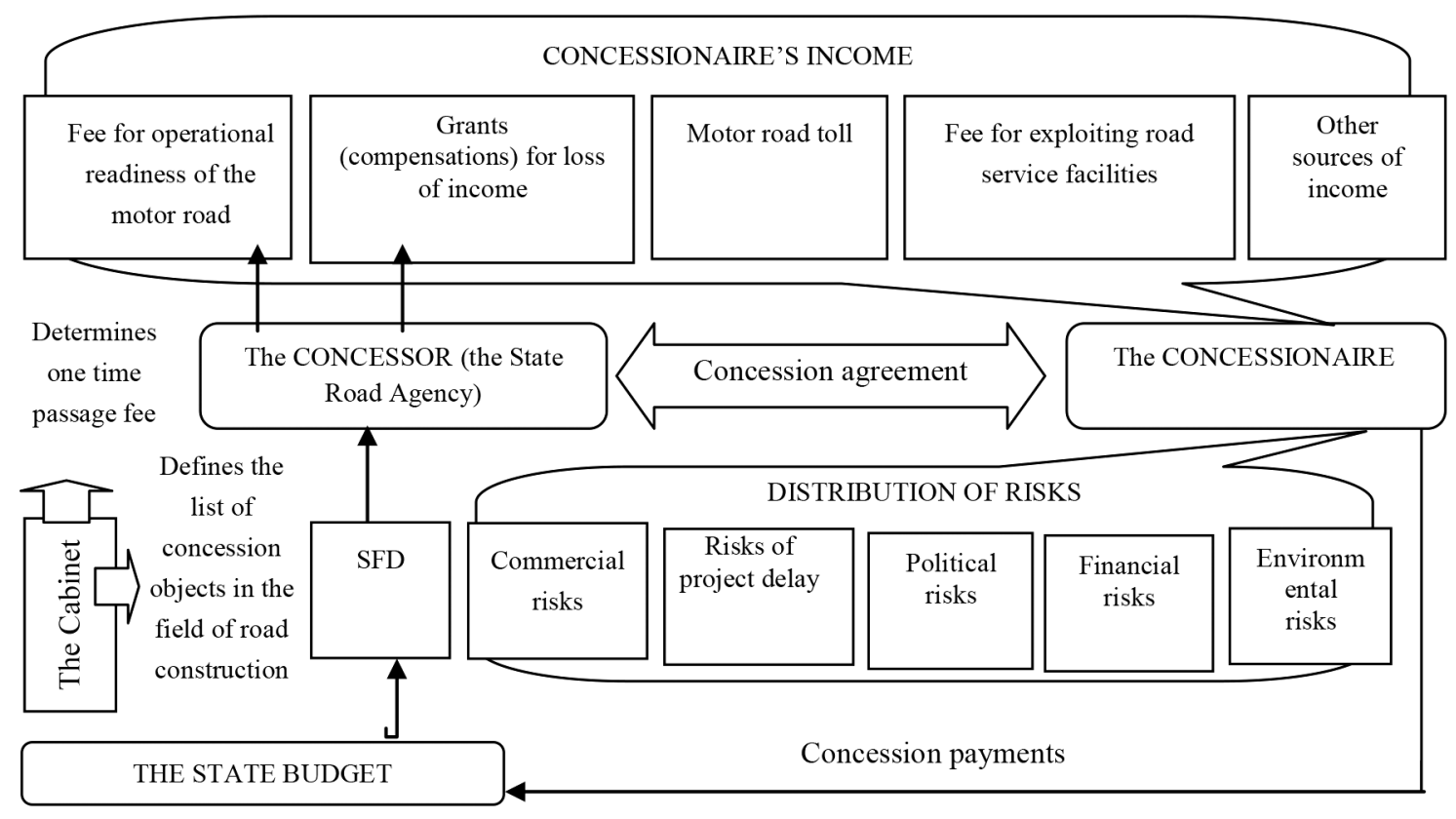

Fig. 2. Scheme of the financial model of concession for the construction and operation of motor roads in Ukraine 


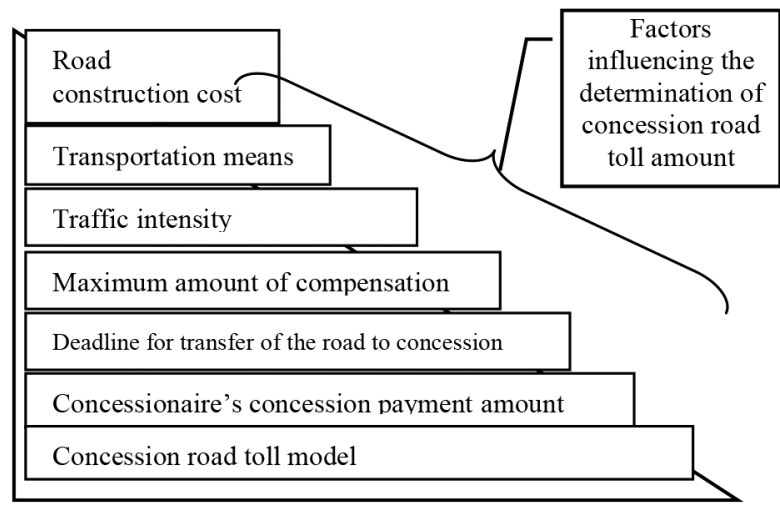

Fig. 3. Factors in fluencing the amount of fees for the use of concession roads

traffic, the Agency will reimburse part of the unearned income in the form of compensation in the amount not exceeding $15 \%$ of the income planned by the concessionaire for that year.

Several conditions are enough to create competition and attract private investors: creating equal conditions for participation in and transparency of tenders, concluding long-term maintenance contracts for a period of $15-25$ years so that investors have the opportunity to return the investment, guarantee of partner risk sharing at the expense of SFD funds and the division of operational maintenance into two types of services - permanent ones (cleaning, painting, and so on), which can be controlled according to the principle of OPRC (payment for the final result), and periodic ones, which include all types of repairs from medium to small ones $[13,14]$. There- fore, Ukraine should not shy away from the experience of European countries, but on the contrary, should study it thoroughly and implement it in the investment activities of road sector, which will guarantee further development of roads and the transport infrastructure taking into account risks [15, 16] and eliminate the need to use funds [17] allocated for countering the COVID-19 virus pandemic.

The fundamental basis for deciding on capital investment is the expected income [18, 19], the amount of which is directly dependent on the toll and the intensity of traffic [20]. In this case, the concession road toll is formed under the influence of the following factors (Fig. 3). Each of these factors has a certain weight and significance in determining the amount of concession road tolls, and therefore requires detailed study. Among these factors, the decisive one is the cost of road construction.

In fact, there are no uniform standards for the cost of road construction in Ukraine or in the EU countries. According to the Stare Road Agency of Ukraine [11], the average cost of road construction during 2015-2018 was (Table 3).

In the course of a comparative analysis of the cost of construction of roads of the first category in the EU and Ukraine, it was found that the cost of construction of $1 \mathrm{~km}$ of road in Ukraine is many times lower than in European countries (Table 4) [14].

In the process of building a model of the dependence of cost of an investment project on the type of road construction work, it was found that current minor repairs and such repairs as the control of damage and deformation of road surfaces, in determining the cost of construction, are statistically insignificant, so they were excluded from the model.

Then the model of dependence of cost of an investment project on the type of road construction works takes the following form

$$
\begin{array}{lcc}
I P_{k}=426835.8+188983.85 \cdot x_{k 1}+10534.85 \cdot x_{k 2}+15536.35 \cdot x_{k 3} \\
(2.35) & (3.06)
\end{array}
$$

Where $I P_{k}$ is the cost of the $k^{\text {th }}$ investment project; $x_{k 1}$ is road construction under the $k^{\text {th }}$ investment project, $\mathrm{km} ; x_{k 2}$ is overhaul under the $k^{\text {th }}$ investment project, $\mathrm{km} ; x_{k 3}$ is current average road repair under the $k^{\text {th }}$ investment project, $\mathrm{km}$.

The value of the coefficient of determination of the model (3) $R^{2}=0.95$ is close to one, which indicates a high quality of the model. Checking the statistical significance of model (3) under Fisher's criterion with $95 \%$ reliability allows us to conclude that the model is statistically significant because the calculated value of criterion $\left(F_{\text {est }}=76.55\right)$ is more than the critical $F_{\text {crit }}(0.05 ; 3 ; 13)=3.41$.

In the model (3), under the coefficients in parentheses, the calculated values of Student's criterion are put. The critical value of Student's criterion $\left(t_{\text {crit }}(0.05 ; 3 ; 13)=2.16\right)$ is less than the corresponding calculated values of criterion, so all the coefficients of model (3) with a $95 \%$ reliability are statistically significant.

Thus, we can draw a general conclusion that the model (3) is qualitative and statistically significant, i. e., it can be used in

the process of making management decisions to determine the value of investment projects. It is also worth noting that, since it is a case of an investment project for road construction, the model (3) includes only the variable $x_{k 1}$, and the variables $x_{k 2}$ and $x_{k 3}$ are equal to zero.

Taking into account the length, for example, of the LvivKrakovets motor road, we found that the implementation of such a project requires 615 million euros (Table 5), i.e., 7.3 million euros per $1 \mathrm{~km}$ [11].

Thus, based on the results of the study on relationship between the cost of an investment project and the volume of works by their types, we proposed an economic and mathematical model for estimating the need for investment in projects for construction, reconstruction, repair and maintenance of public motor roads. The model, unlike the existing ones, is based on a lateral understanding of the clarity of division of capital needs by types of road construction. This will ensure making management decisions on investing in projects using model and information tools that will help obtain the most realistic

Table 3

The average cost of construction of $1 \mathrm{~km}$ of motor roads in Ukraine during 2015-2018

\begin{tabular}{|l|c|c|c|c|c|c|c|c|}
\hline \multirow{2}{*}{ Road category } & \multicolumn{2}{|c|}{2015} & \multicolumn{2}{c|}{2016} & \multicolumn{2}{c|}{2017} & \multicolumn{2}{c|}{2018} \\
\cline { 2 - 10 } & $\$ \mathrm{~m} \ln / \mathrm{km}$ & $€ \mathrm{~m} \ln / \mathrm{km}$ & $\$ \mathrm{~m} \ln / \mathrm{km}$ & $€ \mathrm{~m} \ln / \mathrm{km}$ & $\$ \mathrm{~m} \ln / \mathrm{km}$ & $€ \mathrm{~m} \ln / \mathrm{km}$ & $\$ \mathrm{~m} \ln / \mathrm{km}$ & $€ \mathrm{mln} / \mathrm{km}$ \\
\hline I category & 2.379 & 2.26 & 2.755 & 2.62 & 3.270 & 2.87 & 3.408 & 3.21 \\
\hline II category & 1.237 & 1.18 & 1.432 & 1.36 & 1.524 & 1.59 & 1.654 & 2.01 \\
\hline III category & 1.118 & 1.06 & 1.295 & 1.23 & 1.401 & 1.38 & 1.594 & 1.67 \\
\hline IV category & 0.618 & 0.59 & 0.716 & 0.68 & 0.859 & 0.84 & 1.028 & 1.29 \\
\hline V category & 0.150 & 0.14 & 0.174 & 0.17 & 0.179 & 0.36 & 0.345 & 0.61 \\
\hline
\end{tabular}


Table 4

The average cost of construction of first category roads in Ukraine and EU countries in 2017

\begin{tabular}{|l|c|}
\hline \multicolumn{1}{|c|}{ Country } & Construction cost, $€ \mathrm{mln} / \mathrm{km}$ \\
\hline Germany & 19 \\
\hline Austria & 15 \\
\hline Hungary & 12.9 \\
\hline Poland & 5.0 \\
\hline Bulgaria & 3.0 \\
\hline Ukraine & 3.16 \\
\hline
\end{tabular}

results of estimating capital requirements needed to improve the transport and operational condition of roads in Ukraine.

No less important factor influencing the amount of payment for the use of concession roads is the intensity of traffic (traffic flow). As it has to be determined separately for each of the types of vehicles, we will first and foremost focus on their current classification in Europe. In EU countries, vehicles are classified as follows when determining the fee for the use of concession roads (Table 6) [14].

According to Table 7, we can observe that, in some countries, in particular, such as Slovakia and the Czech Republic, when determining the fee for the use of concession roads, they distinguish three types of vehicles [16]. In Austria, Hungary and Slovenia, when determining tolls on concession roads, vehicles are classified into four types depending on their techni-

Table 5

Dynamics of the investment in the project for the construction of Lviv-Krakovets motor road under the condition of public-private partnership in the form of concession for the period of 2019-2023

\begin{tabular}{|l|c|c|c|c|c|}
\hline \multirow{2}{*}{ Indicators } & \multicolumn{5}{|c|}{ Years } \\
\cline { 2 - 6 } & 2019 & 2020 & 2021 & 2022 & 2023 \\
\hline \multicolumn{7}{|c|}{ Investing } \\
\hline $\begin{array}{l}\text { Expected } \\
\text { investing, \$ mln. }\end{array}$ & 26.694 & 81.835 & 183.809 & 195.066 & 157.984 \\
\hline \multicolumn{7}{|c|}{} & - & 10.1 & 25.5 & 27.2 & 21.6 \\
\hline $\begin{array}{l}\text { Construction, } \\
\text { km }\end{array}$ & - & - & - & - & - \\
\hline Overhaul, km & 2.6 & - & - & - & - \\
\hline $\begin{array}{l}\text { Running repair, } \\
\text { km }\end{array}$ & 19.8 & - & & & \\
\hline
\end{tabular}

Table 6

Classification of vehicles in EU countries, which is taken into account when determining the fee for the use of concession roads

\begin{tabular}{|l|c|c|c|c|}
\hline \multirow{2}{*}{ Country } & \multicolumn{4}{|c|}{ Types of vehicles } \\
\cline { 2 - 5 } & I & II & III & IV \\
\hline Austria & motorcycles & $\begin{array}{c}\text { cars lighter } \\
\text { than } 3.5 \mathrm{t}\end{array}$ & $\begin{array}{c}\text { cars heavier } \\
\text { than } 3.5 \mathrm{t}\end{array}$ & trailers \\
\hline Hungary & $\mathrm{D} 1$ & $\mathrm{D} 2$ & $\mathrm{~B} 2$ & $\mathrm{U}$ \\
\hline Slovenia & 1 & $2 \mathrm{~A}$ & $2 \mathrm{~B}$ & - \\
\hline Slovakia & - & $\begin{array}{c}\text { cars lighter } \\
\text { than } 3.5 \mathrm{t}\end{array}$ & $\begin{array}{c}\text { cars heavier } \\
\text { than } 3.5 \mathrm{t}\end{array}$ & trailers \\
\hline $\begin{array}{l}\text { Czech } \\
\text { Republic }\end{array}$ & - & $\begin{array}{c}\text { cars lighter } \\
\text { than } 3.5 \mathrm{t}\end{array}$ & $\begin{array}{c}\text { cars heavier } \\
\text { than } 3.5 \mathrm{t}\end{array}$ & trailers \\
\hline
\end{tabular}

cal characteristics, impact on road wear and environmental pollution.

Payments by the concessor in favor of the concessionaire may be made in the form of a fee for operational readiness [19]. The terms of concession agreement which provide for a fee for operational readiness may also provide for the payment of concession fees in case of exceedance of the actual indicators of demand and/or supply over the expected ones specified in the concession agreement [11].

The procedure for calculating the concession payment in particular in Ukraine is provided by the Methodology for Calculating Concession Payments approved by the Resolution of the Cabinet of Ministers of 04.02.2016 \#130 (as amended) (Cabinet of Ministers of Ukraine (2016). Methods of calculating concession payments: Resolution.), which schematically takes the following form (Fig. 4).

Taking into account its shortcomings identified over time, the methodological approach to calculating concession payment has been modified; now, it is based on the stakeholder approach for brown-field and green-field projects on motor road concessions, which, unlike the existing ones, being based on the variability of goals and scenarios of road development, provides for the formation, according to a nomothetic approach, of a model of payment for the use of concession roads based on the distance of travel of a vehicle, its gross weight and the level of impact on the wear and deformation of road surface, on the road capacity and the road load factor. The introduction of proposed methodological approach to the calculation of concession fee will allow having a more realistic assessment of the payback period of road construction projects under public-private partnership in the form of concession.

Conclusions. Analyzing the effectiveness of organizational and economic mechanism for managing the investment activities of road sector, evaluating the efficacy of mechanism for co-financing investment projects under programs for construction, reconstruction, repair and maintenance of roads by international financial organizations as well as diagnosing the efficiency of investment of construction of public roads under public-private partnership in the form of concession allowed drawing the following conclusions:

1. It is stated that the road sector belongs to the strategic sectors of national economy and is an important component of the infrastructural potential of Ukraine. However, the development of motor road network and ensuring its quality, in accordance with international standards, requires significant financial resources incomparable with the capabilities of state budget. Therefore, financing relevant infrastructure projects under public-private partnership in the form of concession is the most attractive for Ukraine.

The sources and level of financial support for the repair and development of motor road network are analyzed. It has been established that in recent years, there has been a phenomenon of turbulence in the investment of projects for the construction and repair of public roads - a range of fluctuations and vortices of capital investment, which hinders the development of national transport system.

2. It is established that the construction of most roads in Ukraine is co-financed by the International Bank for Reconstruction and Development, the European Investment Bank and other international financial organizations, in particular, under the projects "Second Road Improvement and Road Safety Project", "Road Industry Development Project" and "European Roads of Ukraine II" ("Improvement of Transport and Operational Condition of Motor Roads on the Approaches to Kyiv"). In total, at the stage of implementation in this sector of the economy, there are the above three projects, the total amount of loans for which is 1 billion 10 million US dollars and 900 million euros.

The inefficiency of road construction at the expense of international financial organizations has been proved, as evi- 


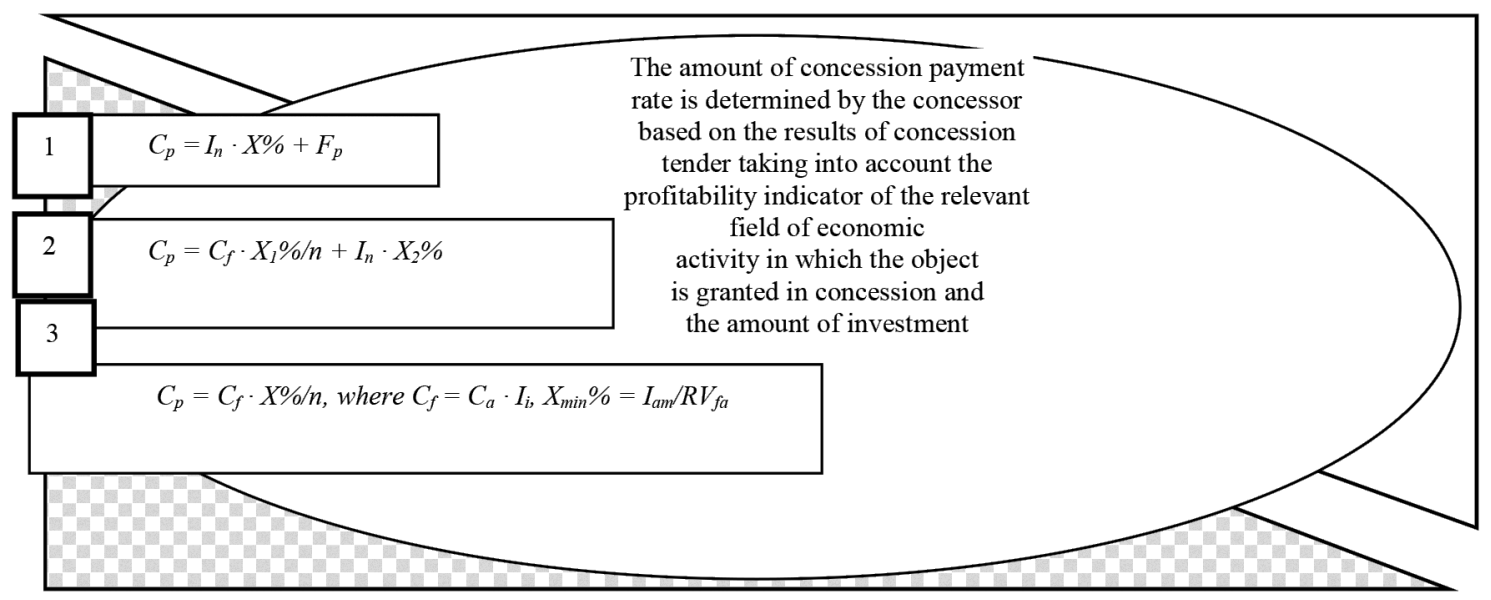

Fig. 4. Scheme of the calculation of concession payment during the operation of a concession object in Ukraine:

$I_{n}$ is net income from conducting concession activities for the relevant reporting period (quarter/year); $X \%$ is the rate of concession payment, percent; $F_{p}$ is the amount of fixed concession payment determined according to the results of concession tender; $n$ is the reporting period (quarter (4)/year); $C_{f}$ is the cost of the object granted in concession, adjusted for inflation index for the relevant period; $C_{a}$ is the cost of the object granted in concession based on the results of its evaluation (revaluation) carried out in the manner prescribed by the legislation on property evaluation, property rights and professional evaluation activities; $I_{i}$ is the inflation index from the date of evaluation (revaluation) of the object granted in the concession until the moment of accrual of concession payment for the reporting period; $I_{a m}$ is the arithmetic mean value of net income starting from the sale of services for the three years preceding the year of conclusion of concession agreement; $R V_{f a}$ is the arithmetic mean value of residual value of fixed assets granted in concession for the three years preceding the year of conclusion of concession agreement

denced by the commissions paid as of June 30, 2017 for commitments (for the unused part of loan) under joint projects with IFOs implemented during 2014-2016, totaling 33.42 million euros and $\$ 6.59$ million US dollars.

3. Based on the analysis of course of homeostasis, the paper proposed a mechanism of co-financing investment projects under motor road development programs with funds of IBRD, EBRD and EIB with "dosed" moderate tolerant selection of investment projects from a set of possible options under active manipulation of destabilization factors, the introduction of systems of instability control and limited chaotization of financing investment activities of the road sector, which will ensure the efficiency of capital investment and reduce the credit burden on regional motor road services.

4. It is substantiated that the key to avoiding the phenomenon of turbulence in the investment of road industry is to create real conditions for attracting private investment in the development of road infrastructure in Ukraine and for practical application of a mechanism for road construction and operation concessions. It is established that one of the determining factors influencing the decision to invest capital in the development of motor roads and transport infrastructure under terms of a concession is the size of concession payment as well as the availability of a system of tax incentives for concessionaires.

5. The methodological approach to calculating concession payment has been modified; now, it is based on the stakeholder approach for brown-field and green-field projects on motor road concessions, which, unlike the existing ones, being based on the variability of goals and scenarios of road development, provides for the formation, according to a nomothetic approach, of a model of payment for the use of concession roads based on the distance of travel of a vehicle, its gross weight and the level of impact on the wear and deformation of road surface, on the road capacity and the road load factor, which will allow having a more realistic assessment of the payback period of road construction projects under public-private partnership in the form of concession.

\section{References.}

1. Laishram, B. S., \& Kalidindi, S. N. (2009). Desirability rating analysis for debt financing of public-private partnership road projects. Construction management and economics, 27(9), 823-837. https://doi.org/10.1080/01446190903222387.

2. Eurostat (2018). Enlargement countries-transport statistics Retrieved from https://ec.europa.eu/eurostat/statistics.

3. Rekova, N., Dolozina, I., Nitsenko, V., Zaitsev, Y., \& Zamlynskyi, V. (2018). Budgetary revenue structure at central level of public administration in the federal countries. Administratie si Management Public, 30, 37-50. https://doi.org/10.24818/ amp/2018.30-03.

4. Rokicki, B., \& Stępniak, M. (2018). Major transport infrastructure investment and regional economic development-An accessibility-based approach. Journal of Transport Geography, 72, 36-49. https://doi.org/10.1016/i.jtrangeo.2018.08.010.

5. Stroiko, T., \& Bondar, V. (2017). Transport infrastructure of Ukraine: The modern realities and development prospects. Baltic Journal of Economic Studies, 3(2), 141-146. https://doi.org/10.30525/2256-0742/2017-3-2-141-146.

6. Revoltella, D., Brutscher, P. B., Tsiotras, A., \& Weiss, C. (2016). Infrastructure investment in Europe and international competitiveness. EIB Working Papers. Retrieved from https:// www.eib.org/attachments/efs/economics working_paper_2016_01_en.pdf.

7. Chukurna, O., Nitsenko, V., Kralia, V., Sahachko, Y., Morkunas, M., \& Volkov, A. (2019). Modelling and Managing the Effect of Transferring the Dynamics of Exchange Rates on Prices of Machine-Building Enterprises in Ukraine. Polish Journal of Management Studies, 19(1), 117-129. https://doi. org/10.17512/pjms.2019.19.1.09.

8. Ieromyna, M. O., Karacharova, K.A., Kirdina, O. G., Dykan, V.V., \& Bilous, L. B. (2018). Financial Prerequisites for the Implementation of EU Directives at the Railway Transport in Ukraine. International Journal of Engineering and Technology, 7(4.3), 603-606. https://doi.org/10.14419/ijet. v7i4.3.19965.

9. Chukurna, O., Nitsenko, V., Kralia, V., Sahachko, Y., Morkunas, M., \& Volkov, A. (2019). Modelling and Managing the Effect of Transferring the Dynamics of Exchange Rates on Prices of Machine-Building Enterprises in Ukraine. Polish Journal of Management Studies, 19(1), 117-129. https://doi. org/10.17512/pjms.2019.19.1.09.

10. Nitsenko, V., Kotenko, S., Hanzhurenko, I., Mardani, A., Stashkevych, I., \& Karakai, M. (2020). Mathematical Modeling of Multimodal Transportation Risks. In: Ghazali R., 
Nawi N., Deris M., Abawajy J. (eds). Recent Advances on Soft Computing and Data Mining. SCDM 2020. Advances in Intelligent Systems and Computing, 978, (pp. 439-447). Springer, Cham. https://doi.org/10.1007/978-3-030-36056-6 41.

11. State Agency of Motor Roads of Ukraine (2017). Report of the 2014-2017. Retrieved from https://www.kmu.gov.ua.

12. Kalinichenko, A., Havrysh, V., \& Nitsenko, V. (2019). Alternative Vehicle Fuel Management: Impact on Energy Security Indicators. In: Krakowiak-Bal, A., \& Vaverkova, M. (Eds.). Infrastructure and Environment, (pp. 367-374). Springer, Cham. https://doi.org/10.1007/978-3-030-16542045.

13. Andriushchenko, K., Tepliuk, M., Boniar, S., Ushenko, N., \& Liezina, A. (2019). Influence of cost drivers on value-oriented management of investment activity of companies. Investment Management and Financial Innovations, 9(1), 353364. https://doi.org/10.21511/imfi.16(3).2019.31.

14. Laird, J. J., \& Venables, A. J. (2017). Transport investment and economic performance: A framework for project appraisal. Transport policy, 56, 1-11. https://doi.org/10.1016/j.tranpol.2017.02.006.

15. Hutsaliuk, O., Koval, V., Tsimoshynska, O., Koval, M., \& Skyba, H. (2020). Risk Management of Forming Enterprises Integration Corporate Strategy. TEM Journal, 9(4), 15141523. https://doi.org/10.18421/TEM94-26.

16. Vochozka, M., Rowland, Z., \& Vrbka, J. (2016). Financial analysis of an average transport company in the Czech Republic. NAŠE MORE, 63(3), 227-236. https://doi.org/10.17818/ NM/2016/SI28.

17. Arata, M., Petrangeli, M., \& Longo, F. (2016). Innovative approaches to implement road infrastructure concession through Public-Private Partnership (PPP) initiatives: a case study. Transportation Research Procedia, 14, 343-352. https:// doi.org/10.1016/j.trpro.2016.05.086.

18. Goncharuk, A.G., Havrysh, V.I., \& Nitsenko, V.S. (2018). National features for alternative motor fuels market. International Journal of Energy Technology and Policy, 14(2/3), 226-249. https://doi.org/10.1504/IJETP.2018.090681.

19. Kwilinski, A., Ruzhytskyi, I., Patlachuk, V., Patlachuk, O., \& Kaminska, B. (2019). Environmental Taxes as a Condition of Business Responsibility in the Conditions of Sustainable Development. Journal of Legal, Ethical and Regulatory Issues, 22(25), 1-6. Print ISSN: 1544-0036; Online ISSN: 1544-0044.

20. Villalba-Romero, F., \& Liyanage, C. L. (2016). Evaluating success in PPP road projects in Europe: a comparison of performance measurement approaches. Transportation Research Procedia, 14, 372-381. https://doi.org/10.1016/j.trpro.2016.05.089.

\section{Інвестування інфраструктурних проектів будівництва доріг за державно-приватного партнерства у формі конщесії}

\section{О. В. Цімошинська ${ }^{1}$, М. І. Коваль ${ }^{1}$, Г. О. Кришталь ${ }^{1}$, Л. М. Філіпішина ${ }^{2}$, А. В. Е. Арсаван ${ }^{3}$, В. В. Коваль ${ }^{4}$}

1 - Міжрегіональна Академія управління персоналом, м. Київ, Україна, e-mail: ovmichailenko@ukr.net

2 - Національний університет біоресурсів і природокористування України, м. Київ, Україна

3 - Балійська державна політехніка, Балі, Індонезія

4 - Одеський торговельно-економічний інститут Київського національного торговельно-економічного університету, м. Одеса, Україна

Мета. Обгрунтувати підхід до управління інвестиційною діяльністю розвитку дорожнього господарства України за дотримання принципу синкретизму й використання методики Quality Function Deployment, удосконалити методичний підхід до розрахунку концесій- ного платежу за brown-field- та green-field-проектами 3 концесії автодоріг.

Методика. У ході дослідження використана сукупність загальнонаукових і спеціальних методів пізнання: метод Quality Function Deployment (QFD), інвайроментальний підхід, мультимодальний аналіз, декаплінг-індекс (Decoupling Index), декаплінг-фактор (Decoupling Factor), логічне узагальнення, кількісне та якісне порівняння, наукове абстрагування й систематизація.

Результати. За результатами дослідження взаємозв'язку вартості інвестиційного проекту та обсягів робіт за їх видами нами запропонована економіко-математична модель оцінювання потреби в інвестиціях за проектами з будівництва, реконструкції, ремонту та утримання автомобільних доріг загального користування. Запропонована модель, на відміну від існуючих, заснована на латеральному осмисленні чіткості розмежування потреби в капіталі за видами робіт із розбудови доріг, що забезпечить прийняття управлінських рішень щодо інвестування проектів модельним і інформаційним інструментарієм, що сприятиме отриманню реалістичного оцінювання потреби в капіталі, необхідному для покращення транспортно-експлуатаційного стану автодоріг в Україні.

Наукова новизна. Удосконалено організаційно-економічний механізм управління інвестиційною діяльністю дорожнього господарства та оцінювання ефективності співфінансування інвестиційних проектів за програмами з будівництва, реконструкції, ремонту та утримання автодоріг. Покращена діагностика ефективності інвестування будівництва автомобільних доріг загального користування на умовах державно-приватного партнерства у формі концесії.

Практична значимість. Результати дослідження можуть бути використані в діяльності дорожнього господарства України для розроблення та впровадження інвестиційних проектів за програмами розбудови автодоріг.

Ключові слова: автомобільні дороги, інвестиції, управління інвестиційною діяльністю, інфраструктурні проекти, державно-приватне партнерство

\section{Инвестирование инфраструктурных проектов строительства дорог по государственно-частному партнерству в форме концессии}

\section{О. В. Цимошинская ${ }^{1}$, Н. И. Коваль ${ }^{1}$, Г. А. Кришталь ${ }^{1}$ Л. М. Филипишина ${ }^{2}$, А. В.Е.Арсаван ${ }^{3}$, В. В. Коваль ${ }^{4}$}

1 - Межрегиональная Академия управления персоналом, г. Киев, Украина, e-mail: ovmichailenko@ukr.net 2 - Национальный университет биоресурсов и природопользования Украины, г. Киев, Украина

3 - Балийская государственная политехника, Бали, Индонезия

4 - Одесский торгово-экономический институт Киевского национального торгово-экономического университета, г. Одесса, Украина

Цель. Обосновать подход к управлению инвестиционной деятельностью развития дорожного хозяйства Украины при соблюдении принципа синкретизма и использования методики Quality Function Deployment, yсовершенствовать методический подход к расчету концессионного платежа за brown-field- и green-field-проектами по концессии автодорог.

Методика. В ходе исследования использованы совокупность общенаучных и специальных методов позна- 
ния: метод Quality Function Deployment (QFD), инвайроментальний подход, мультимодальный анализ, декаплинг-индекс (Decoupling Index), декаплинг-фактор (Decoupling Factor), логическое обобщение, количественное и качественное сравнение, научное абстрагирование и систематизация.

Результаты. По результатам исследования взаимосвязи стоимости инвестиционного проекта и объемов работ по их видам нами предложена экономико-математическая модель оценки потребности в инвестициях по проектам строительства, реконструкции, ремонта и содержания автомобильных дорог общего пользования. Предложенная модель, в отличие от существующих, основана на латеральном осмыслении четкости разграничения потребности в капитале по видам работ относительно развития дорог, обеспечит принятие управленческих решений по инвестированию проектов модельным и информационным инструментарием, который будет способствовать получению реалистичной оценки потребности в капитале, необходимом для улучшения транспортно-эксплуатационного состояния автодорог в Украине.
Научная новизна. Усовершенствован организационно-экономический механизм управления инвестиционной деятельностью дорожного хозяйства и оценки эффективности софинансирования инвестиционных проектов по программам строительства, реконструкции, ремонта и содержания автодорог. Улучшена диагностика эффективности инвестирования строительства автомобильных дорог общего пользования на условиях государственно-частного партнерства в форме концессии.

Практическая значимость. Результаты исследования могут быть использованы в деятельности дорожного хозяйства Украины для разработки и внедрения инвестиционных проектов по программам развития автодорог.

Ключевые слова: автомобильные дороги, инвестиции, управление инвестиционной деятельностью, инфраструктурные проекты, государственно-частное партнерство

Recommended for publication by O.Datsii, Doctor of Economic Sciences. The manuscript was submitted 08.11.20. 